\title{
Cities and the Biosphere
}

\author{
This article belongs to Ambio's 50th Anniversary Collection. Theme: Urbanization
}

\author{
Carl Folke, Åsa Gren, Jonas Larsson, Robert Costanza
}

Sustainable cities have been in focus for a long time. Our journey with this paper (Folke et al. 1997) goes back to the mid-1990s when the United Nations Habitat II conference was held in Istanbul, Turkey, with a focus on fostering sustainable human settlements in its diverse dimensions. But, the supporting land area of cities, their ghost acreage or hinterland, was largely out of sight and thereby also out of mind (Borgström 1974).

Earlier, Vitousek et al. (1986) had published a paper in BioScience on human appropriation of the products of photosynthesis. This work inspired our paper 'Ecosystem Appropriation by Cities' (Folke et al. 1997). Our goal was to place cities as part of their broader global biosphere context and investigate the extent to which cities actually were dependent upon the life-supporting ecosystems and the environmental functions and ecosystem services those generate. Or more specifically, to analyse how dependent cities actually are on resilient ecosystems. As described in Deutsch et al. (2000), our 'ecological footprint' approach was different from the more popular use of the concept. Using available ecological data and knowledge of local and regional ecosystem performance, we centred on food and timber consumption and waste assimilation, developing and drawing on several databases and sources of information. We focused on the thirty largest cities in the Baltic Sea drainage basin and also performed an analysis of the, at that time, world's megacities and how much of the work of the oceans they appropriated for seafood consumption and of the world's forests for carbon sequestration.

The work with and results of this paper have been very useful in the years since its publication, to illustrate and clarify, in lectures, seminars, for practice, policy and business, that irrespective of preferences for nature or whether or not people in cities appreciate the broader biosphere, they still fundamentally depend on nature's contributions for wellbeing. But nature's work tends to be 'hidden' because it is generally unseen in urban lifestyles and people and policy seldom fully appreciate this work. Nevertheless it is very real. Here, we estimated that nature's contributions in providing the cities with food and timber and absorbing waste corresponded to an ecosystem area some one thousand times larger than the area of the city itself. Our estimates also suggested that the seafood consumption of megacities appropriated some $25 \%$ of the world's productive oceans, while the need for carbon sequestration of the emission of megacities exceeded the sink capacity of the world's forests. Hence, we highlighted the 'mental disconnect' between many city dwellers and the realities and implications of being embedded in the broader biosphere.

These were early days of a now rapidly expanding research area of urban ecology, the urban planet and the significant role of urbanisation in the Anthropocene. Our paper was followed by Grimm et al. (2008) ten years later. More recently there has been beautiful work on cities and land use as well as cities and their central role in shaping the planet's biodiversity and many, many more amazing contributions impossible to review here (e.g. Seto et al. 2012; Alberti et al. 2017).

Today, the urban-biosphere interplay is increasingly visible, perhaps particularly in the food realm where the production of huge quantities of bulk food in vast vulnerable monocultures is put into perspective (Gordon et al. 2017). As a contrast, high quality food as part of biocultural landscapes and carrier of multiple social and ecological values is increasingly appreciated and a much richer interpretation of cities within the biosphere than studies of urban metabolism alone (Andersson et al. 2014).

Now in the Anthropocene, when people and nature are deeply intertwined, biosphere support can no longer be 
taken for granted. Currently, with climate change, pandemics and social and economic turbulence, it has become increasingly evident that in the Anthropocene all human dimensions of life are embedded within, intertwined with, and dependent upon the biosphere (Folke et al. 2011) and urbanisation is central in this complex dynamics. In this context, it is surprising that many contemporary approaches to urban development and policy still are constructed on the mistaken belief that humanity is external to the biosphere (Gren et al. 2019).

Humans, our actions, institutions, and governance systems, will have to foster active stewardship of our own future on planet Earth. In an urban context, biosphere stewardship of the twenty-first century involves actions that reconnect people and development to the biosphere foundation (Folke et al. 2011), engaging actors and institutions from within cities to the urban planet as a whole (Krasny and Tidball 2012; Seitzinger et al. 2012; Andersson et al. 2014; Elmqvist et al. 2018; Webb et al. 2018). Sustainable urbanisation will require joint strategies and incentives between city dwellers and the stewards of the landscapes and seascapes upon which city life depends. This involves collective action, with trust and a deep appreciation and respect for the skills and competencies involved with biosphere stewardship (Andersson et al. 2014; West et al. 2018).

Clearly, city planning and development have to take the Anthropocene challenge very seriously and understand and act upon the situation. Transformations that reconnect urbanisation to the broader biosphere foundation are urgently needed and fundamental for sustainable futures (Elmqvist et al. 2019).

\section{REFERENCES}

Alberti, M., C. Correa, J.M. Marzluff, A.P. Hendry, E.P. Palkovacs, K.M. Gotanda, V.M. Hunt, T.M. Apgar, et al. 2017. Global urban signatures of phenotypic change in animal and plant populations. Proceedings of the National Academy of Sciences USA 114: 8951-8956.

Andersson, E., S. Barthel, S. Borgström, J. Colding, T. Elmqvist, C. Folke, and A. Gren. 2014. Reconnecting cities to the biosphere: Stewardship of green infrastructure and urban ecosystem services. Ambio 43: 445-453.

Borgström, G. 1974. The food-population dilema. Ambio 3: 109-113.

Deutsch, L., A. Jansson, M. Troell, P. Rönnbäck, C. Folke, and N. Kautsky. 2000. The "ecological footprint": Communicating human dependence on nature's work. Ecological Economics 32: 351-355.

Elmqvist, T., X. Bai, N. Frantzeskaki, C. Griffith, D. Maddox, T. McPhearson, S. Parnell, P. Romero-Lankao, et al. (eds.). 2018. Urban planet: Knowledge towards sustainable cities. Cambridge: Cambridge University Press.
Elmqvist, T., N. Frantzeskaki, E. Andersson, T. McPhearson, C. Folke, P. Olsson, O. Gaffney, and K. Takeuchi. 2019. Sustainability, resilience and transformation in the urban century. Nature Sustainability 2: 267-273.

Folke, C., Å. Jansson, J. Rockström, P. Olsson, S.R. Carpenter, F.S. Chapin, A.-S. Crépin, G. Daily, et al. 2011. Reconnecting to the biosphere. Ambio 40: 719-738.

Folke, C., Å. Jansson, J. Larsson, and R. Costanza. 1997. Ecosystem appropriation by cities. Ambio 26: 167-172.

Gordon, L.J., V. Bignet, B. Crona, P. Henriksson, T. van Holt, M. Jonell, T. Lindahl, M. Troell, et al. 2017. Rewiring food systems to enhance human health and biosphere stewardship. Environmental Research Letters 12: 100201.

Gren, Å., M. Berghauser-Pont, J. Colding, and L. Marcus. 2019. How smart is smart growth? Examining the environmental validation behind city compaction. Ambio 48: 580-589.

Grimm, N.B., S.H. Faeth, N.E. Golubiewski, C.L. Redman, J. Wu, X. Bai, and J.M. Briggs. 2008. Gloal change and the ecology of cities. Science 319: 756-760.

Krasny, M.E., and K.G. Tidball. 2012. Civic ecology: A pathway for Earth stewardship in cities. Frontiers in Ecology and the Environment 10: 267-273.

Seitzinger, S.P., U. Svedin, C.L. Crumley, W. Steffen, S.A. Abdullah, C. Alfsen, W.J. Broadgate, F. Biermann, et al. 2012. Planetary stewardship in an urbanizing world: Beyond city limits. Ambio 41: 787-794.

Seto, K.C., A. Reenberg, C.G. Boone, M. Fragkias, D. Haase, T. Langanke, P. Marcotullio, D.K. Munroe, et al. 2012. Urban land teleconnections and sustainability. Proceedings of the National Academy of Sciences USA 109: 7687-7692.

Vitousek, P.M., P.R. Ehrlich, A.H. Ehrlich, and P.A. Matson. 1986. Human appropriation of the products of photosynthesis. BioScience 36: 368-373.

Webb, R., X. Bai, M. Stafford Smith, R. Costanza, D. Griggs, M. Moglia, M. Neuman, P. Newman, et al. 2018. Sustainable urban systems: Co-design and framing for transformation. Ambio 47: 57-77.

West, S., L.J. Haider, V. Masterson, J.P. Enqvist, U. Svedin, and M. Tengö. 2018. Stewardship, care and relational values. Current Opinion in Environmental Sustainability 35: 30-38.

Publisher's Note Springer Nature remains neutral with regard to jurisdictional claims in published maps and institutional affiliations.

\section{Carl Folke $(\bowtie)$}

Address: Stockholm Resilience Centre, Stockholm University, Stockholm, Sweden.

e-mail: carl.folke@beijer.kva.se

\section{Åsa Gren}

Address: Beijer Institute, Royal Swedish Academy of Sciences, Stockholm, Sweden.

e-mail: asa.gren@beijer.kva.se

\section{Jonas Larsson}

Address: Department of Psychology, Royal Holloway, University of London, Egham Hill, Egham, Surrey, England.

e-mail: Jonas.Larsson@rhul.ac.uk

\section{Robert Costanza}

Address: Crawford School of Public Policy, Australian National

University, Canberra, Australia.

e-mail: Robert.Costanza@anu.edu.au 